\title{
NFKB1 polymorphism is associated with age-related gene methylation in Helicobacter pylori-infected subjects
}

\author{
TOMIYASU ARISAWA ${ }^{1}$, TOMOMITSU TAHARA ${ }^{2}$, HISAKAZU SHIROEDA ${ }^{1}$, HIDETO YAMADA ${ }^{1}$, \\ TOMOE NOMURA ${ }^{1}$, RANJI HAYASHI ${ }^{1}$, TAKASHI SAITO ${ }^{1}$, TOMOKI FUKUYAMA ${ }^{1}$, TOSHIMI OTSUKA ${ }^{1}$, \\ MASAKATSU NAKAMURA ${ }^{1}$, NOBUYUKI TOSHIKUNI ${ }^{1}$, MUTSUMI TSUCHISHIMA ${ }^{1}$ and TOMOYUKI SHIBATA ${ }^{2}$ \\ ${ }^{1}$ Department of Gastroenterology, Kanazawa Medical University, Uchinada-machi, Ishikawa 920-0293; ${ }^{2}$ Department \\ of Gatroenterology, Fujita Health University, School of Medicine, Kutsukake-cho, Toyoake 470-1192, Japan
}

Received February 16, 2012; Accepted April 10, 2012

DOI: $10.3892 /$ ijmm.2012.1004

\begin{abstract}
CpG island aberrant methylation is shown to be an important mechanism in gene silencing. The important role of $\mathrm{NF}-\kappa \mathrm{B}$ in the inflammatory response to $H$. pylori colonization has been indicated. We investigated the influence of NFKB1 polymorphisms, -94 ins/del (rs28362491) and -449 C>G (rs72696119), on the aberrant gene methylation under H. pylori infection. Gastric mucosal samples were obtained from subsubjects without malignancies. Methylation status of genes $\left(p 14^{A R F}, p 16^{I N K 4 a}, D A P K\right.$ and $\left.C D H 1\right)$ was determined by methylation-specific PCR (MSP). The genotyping of NFKB1 was performed by PCR-SSCP. There was a strong allelic association between rs28362491 and rs72696119, and all $H$. pylori-infected -94 del/del homozygotes had a -449 GG genotype. The -94 del/ del homozygosity was significantly associated with risk for development of $\mathrm{CpG}$ island high methylation (CIHM) (two or more gene methylations), especially $D A P K$ and $C D H 1$ methylations, and the number of methylated genes was significantly higher in -94 del/del homozygotes than in ins/del and ins/ins (ins carrier) $H$. pylori-infected elder subjects. In addition, this methylated gene number was significantly increased with age in $H$. pylori-infected del/del homozygotes, but not in infected ins carriers. Furthermore, the inflammation score was significantly higher in H.pylori-infected del/del homozygotes compared to ins carriers. NFKB1 -94 ins/del ATTG polymorphism (rs28362491) was significantly associated with the increased risk for the development of age-related gene methylation in non-cancerous gastric mucosa under $H$. pylori-induced inflammation.
\end{abstract}

\section{Introduction}

Helicobacter pylori (H. pylori) infection first induces chronic superficial gastritis, which can progress to chronic atrophic

Correspondence to: Dr Tomiyasu Arisawa, Department of Gastroenterology, Kanazawa Medical University, 1-1 Daigaku, Uchinada-machi, Ishikawa 920-0293, Japan

E-mail: tarisawa@kanazawa-med.ac.jp

Key words: NFKB1, aberrant DNA methylation, Helicobacter pylori infection gastritis, intestinal metaplasia, and dysplasia that leads toward gastric carcinoma (1). Lipopolysaccharide (LPS), which is a component of the outer membrane of Gram-negative bacteria including $H$. pylori, is a signaling molecule for the innate immune system and is one of the main sources of inflammation (2). LPS binding to TLR4 activates signal transduction through MyD88, IRAK and TRAF6 to activate $\mathrm{NF}-\kappa \mathrm{B}$ (3). Activation of NF- $\kappa \mathrm{B}$ by $H$. pylori induces nuclear translocation, which causes an increase in IL- 8 messenger RNA and protein levels (4). Other $N F-\kappa B$ responsive genes including pro-inflammatory cytokines have also been found in elevated levels in $H$. pylori-infected gastric mucosa. In addition, the $\mathrm{NF}-\kappa \mathrm{B}$ pathway is responsible for the generation of several cell adhesion molecules including ICAM-1 whose expression is significantly correlated with an increase in H. pylori-induced gastritis (5). Thus, H. pylori is a potent activator of $N F-\kappa B$ in gastric epithelial cells and $N F-\kappa B$ is a major molecule in $H$. pylori-induced inflammation $(4,6)$. On the other hand, $N F-\kappa B$ activation is known to regulate cellular growth responses, including apoptosis, and is required for the induction of inflammatory and tissue-repair genes (7). These facts suggest that $\mathrm{NF}-\kappa \mathrm{B}$ plays an important role in inflammation-associated carcinogenesis. In fact, $H$. pylori infection, activating $\mathrm{NF}-\kappa \mathrm{B}$, is now accepted as a crucial event in the development of peptic ulcer disease and atrophic gastritis, and it is implicated in the development of gastric carcinoma, especially not located in the cardia (8-10).

Several cancers, including gastric tumors, show methylations of multiple genes $(11,12)$. Some genes are methylated in non-neoplastic tissues with aging $(13,14)$ and these methylations are also under the influence of chronic inflammation $(15,16)$. In non-cancerous gastric mucosa, methylation of $\mathrm{CpG}$ islands was induced by $H$. pylori infection $(17,18)$ and considered as the precancerous conditions in gastric carcinogenesis (19). Among several genes, E-cadherin $(\mathrm{CDH})$, death-associated protein kinase $(D A P K)$ and cyclin-dependent kinase inhibitor $2 \mathrm{~A}$ $(C D K N 2 A)$ are frequently methylated in non-neoplastic gastric mucosa in relation to age, $H$. pylori infection, histological degree of gastritis, and gastric carcinogenesis $(17,20)$. Therefore, there is a possibility that $N F-\kappa B$ activation may affect the gene methylations in $H$. pylori-induced chronic inflammation. Recently, many studies have reported the association between 
the polymorphism, -94 ins/del ATTG (rs28362491) of NFKB1 encoding NF- $\mathrm{KB}$, and various inflammatory diseases (21), as well as malignant neoplasm (22). However, these results do not always lead to the same conclusions. Furthermore, the genetic variation $-449 \mathrm{C}>\mathrm{G}$ in the 5'-UTR of NFKBI (rs72696119) has been identified. There are no reports for the association of this polymorphism and human disorders.

Then, we attempted to clarify the association between the $-94 \mathrm{ins} / \mathrm{del}$ ATTG polymorphism (rs28362491) of NFKB1 and gene methylations in $H$. pylori-infected Japanese subjects. In addition, the $-449 \mathrm{C}>\mathrm{G}$ polymorphism (rs72696119) was also investigated.

\section{Materials and methods}

Clinical samples. The $330 \mathrm{H}$. pylori-infected subjects without peptic ulcers and gastric malignancies, who were enrolled at the Endoscopy Center of Fujita Health University Hospital or Kanazawa Medical University Hospital from January in 2006 to December in 2009, were selected. As a control, 205 $H$. pylori-uninfected subjects were randomly selected from our stocked DNA collected during the same period. Thus, the overall studied population comprised 535 subjects.

All subjects underwent upper endoscopy with biopsy from non-cancerous mucosa in the antrum. Parts of each specimen was fixed in 10\% buffered-formalin and embedded in paraffin, while the other part was immediately frozen and stored at $-85^{\circ} \mathrm{C}$. Later, genomic DNA was isolated from frozen specimens using proteinase $\mathrm{K}$. The patients with severe systemic diseases, malignancies in other organs, and who had received nonsteroidal anti-inflammatory drugs, antibiotics, and H. pylori eradication treatment were excluded. H. pylori infection status was assessed by serology, histological examination, or the urea breath test. Patients were diagnosed as having infection when at least one of the diagnostic tests was positive.

The subjects with 2 or more methylations of 4 genes ( $p 14^{A R F}$, $p 16^{I N K 4 a}, D A P K$ and $C D H 1$ ) were classified into the $\mathrm{CpG}$ island high methylation (CIHM) group, whereas the others except the CIHM group were classified into the non-CIHM group.

The Ethics Committee of the Fujita Health University and the Kanazawa Medical University approved the protocol, and prior, written informed consent was obtained from all participating subjects.

Bisulfate modification and methylation-specific PCR (MSP). In 402 of 535 subjects $(243 \mathrm{H}$. pylori-infected and 159 uninfected), the methylation status of 4 candidate promoter CpG islands ( $p 14, p 16, C D H 1$, and $D A P K$ ), which have been thought to be most susceptible for methylation in the stomach $(12,19,22,23)$, were assessed. For the examination of DNA methylation, genomic DNA was treated with sodium bisulfite using the BislFast DNA Modification kit for methylated DNA detection (Toyobo, Co., Ltd., Osaka, Japan). Methylation status of four candidate promoter $\mathrm{CpG}$ islands were examined by MSP as previously described (24). The primer pairs and experimental conditions for MSP are the same as in our previous study $(13,23,24)$. The MSP was carried out in a volume of $20 \mu \mathrm{l}$ containing $0.1 \mu \mathrm{g}$ of bislufite-modified DNA. The bands of MSP were detected by electrophoresis in 3.0\% agarose gels stained with ethidium bromide. Hypermethylation

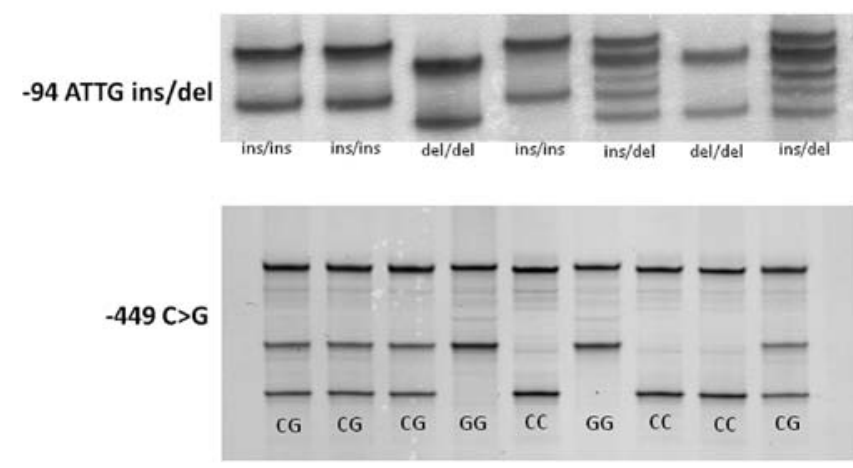

Figure 1. Images of multiplex PCR-SSCP using clinical samples. Single strand DNAs were clearly separated by SSCP.

was defined as the presence of positive methylation band, separated by electrophoresis on $2.5 \%$ agarose gels under UV illumination using an ethidium bromide staining, showing signals approximately equivalent to or greater than that of size marker (10 ng/ $\mu \mathrm{l}: 100$ bp DNA ladder; Takara Bio, Inc., Shiga, Japan), irrespective of the presence of unmethylated bands. We used DNA from the peripheral blood of a young individual without $H$. pylori infection, as the negative control (unmethylated DNA), and also used DNA being treated with SssI methylase (New England Biolabs, Inc., Beverly, MA, USA), as the positive control (methylated DNA). Samples giving faint positive signals were analyzed a further two times and only those samples with consistent positive methylation band were considered as hypermethylation status.

Genotyping of polymorphisms. The DNA isolated from biopsy specimens or peripheral blood was used. The polymorphisms were genotyped by the PCR-SSCP method as previously described $(25,26)$. To detect NFKBI -94 ins/del ATTG using the primer pairs (94-F, 5'-gctatggaccgcatgactctatcag-3' and 94-R, 5'-ggggctctggcttcctagcag-3'), PCR was carried out in a volume of $20 \mu \mathrm{l}$ containing $0.1 \mu \mathrm{g}$ of genomic DNA. The DNA was denatured at $95^{\circ} \mathrm{C}$ for $3 \mathrm{~min}$, followed by 35 cycles at $96^{\circ} \mathrm{C}$ for $15 \mathrm{sec}, 58^{\circ} \mathrm{C}$ for $40 \mathrm{sec}$, and $72^{\circ} \mathrm{C}$ for $30 \mathrm{sec}$, with a final extension at $72^{\circ} \mathrm{C}$ for $5 \mathrm{~min}$. Thereafter, $2 \mu \mathrm{l}$ of the PCR product was denatured with $10 \mu \mathrm{l}$ of formamide (SigmaAldrich Co., St. Louis, MO, USA) at $90^{\circ} \mathrm{C}$ for $5 \mathrm{~min}$. SSCP was carried out at $6^{\circ} \mathrm{C}$ using a GenePhor DNA separation system with GeneGel Excel 12.5/24 (Amersham Biosciences Corp., USA), after which the denatured single strand DNA bands were detected using a DNA Silver Staining kit (Amersham Biosciences Corp.).

To detect the NFKBI $-449 \mathrm{C}>\mathrm{G}$, using the primer pairs (449-F, 5'-cgtgtgtccgtctgtctgtatgctc-3' and 449-R, 5'-cgctggtgcacttctctctctttct-3'), PCR was carried out in a volume of $20 \mu \mathrm{l}$ containing $0.1 \mu \mathrm{g}$ of genomic DNA. The DNA was denatured at $95^{\circ} \mathrm{C}$ for $3 \mathrm{~min}$, followed by 35 cycles at $95^{\circ} \mathrm{C}$ for $30 \mathrm{sec}$, $57^{\circ} \mathrm{C}$ for $40 \mathrm{sec}$, and $72^{\circ} \mathrm{C}$ for $45 \mathrm{sec}$, with a final extension at $72^{\circ} \mathrm{C}$ for $5 \mathrm{~min}$. Thereafter, SSCP was carried out as described above.

Histological evaluation. In 400 of 535 subjects (256 H. pyloriinfected and 144 uninfected subjects), the severity of chronic gastritis was classified according to the updated Sydney 
Table I. Characteristics and prevalence polymorphisms and methylation status.

\begin{tabular}{|c|c|c|c|}
\hline Characteristics & H. pylori-infected & H.pylori-uninfected & p-value ${ }^{a}$ \\
\hline Number of subjects & 330 & 205 & \\
\hline Mean age \pm SD & $61.0 \pm 12.4$ & $59.2 \pm 15.0$ & NS \\
\hline Male:female & 211:119 & $98: 107$ & 0.0003 \\
\hline \multicolumn{4}{|c|}{ NFKB1-94 ins/del ATTG } \\
\hline ins/ins & 119 & 79 & \\
\hline ins/del & 172 & 97 & \\
\hline $\mathrm{del} / \mathrm{del}$ & 39 & 29 & \\
\hline del allele frequency & $37.9 \%$ & $37.8 \%$ & NS \\
\hline \multicolumn{4}{|l|}{$N F K B 1-449 \mathrm{G}>\mathrm{C}$} \\
\hline $\mathrm{CC}$ & 124 & 83 & \\
\hline CG & 161 & 91 & \\
\hline GG & 45 & 31 & \\
\hline $\mathrm{G}$ allele frequency & $38.0 \%$ & $37.3 \%$ & NS \\
\hline \multicolumn{4}{|c|}{ Methylated:unmethylated } \\
\hline$p 14^{A R F}$ & $90: 153$ & $44: 115$ & 0.053 \\
\hline$p 16^{I N K 4 a}$ & $91: 152$ & $21: 138$ & $<0.0001$ \\
\hline$C D H 1$ & 109:134 & $38: 121$ & $<0.0001$ \\
\hline$D A P K$ & 139:104 & $58: 101$ & $<0.0001$ \\
\hline CIHM/non-CIHM & $136 / 107$ & $47 / 112$ & $<0.0001$ \\
\hline
\end{tabular}

${ }^{\mathrm{a}} H$. pylori-infected vs. H. pylori-uninfected. NS, not significant; CIHM, CpG island high methylation group.

system (27) by a pathologist who had no access to any clinical information.

Statistical analysis. The data were expressed as mean \pm SD. The mean age among the two groups was compared by the Student's t-test. The ratios of gender and gene methylation were compared by the Fisher's extract test. The strength of association between allele frequencies and the methylation status was assessed by calculating the odds ratio (OR) and 95\% confidence intervals (CI) by logistic regression analysis. Adjusted ORs were calculated after adjustment for age and gender. Each updated Sydney system score between the 2 groups were compared by the Mann-Whitney U-test. The methylation status was compared among the 2 groups by ANOVA. The relationship between age and the number of methylated genes was also assessed by ANOVA. Concerning the power of study, the $\beta$-value was calculated when setting $\alpha=0.05$. For all analyses, the level of significance was set at $\mathrm{p}<0.05$.

\section{Results}

Subjects and genotype. As shown in Fig. 1, single strand DNAs of each polymorphism were clearly identified by SSCP. The characteristics of the subjects are summarized in Table I. The overall distribution of -94 ins/del ATTG genotype was 198 ins/ ins, $269 \mathrm{ins} / \mathrm{del}$ and $68 \mathrm{del} / \mathrm{del}$. The distribution of $-449 \mathrm{C}>\mathrm{G}$ was $207 \mathrm{CC}, 252 \mathrm{CG}$ and $76 \mathrm{GG}$. There was a strong allelic association between -94 ins/del ATTG and $-449 \mathrm{C}>\mathrm{G}$. The frequencies of distributions of both genotypes, in the HardyWeinberg equilibrium ( $\mathrm{p}=0.12$ and 1.00 , respectively), were not significant difference among $H$. pylori-infected a d uninfected subjects. The male/female ratio was lower and each gene methylation ratio, except $p 14^{A R F}$, was higher in $H$. pylori-infected subjects than uninfected subjects. The CIHM/non-CIHM ratio was also significantly higher in $H$. pylori-infected subjects.

Association between NFKB1 polymorphisms and CIHM. We defined the subjects with 2 or more gene methylations as the CIHM group, because the overall average number of gene methylation was 1.58. NFKB1 -94 del/del homozygotes had an increased risk for the development of CIHM in H. pyloriinfected over 60-year-old subjects (OR, 4.16; 95\% CI, 1.14-15.3; $\mathrm{p}=0.031$ and $\beta=0.674$ ) (Table II), although no significant risk was seen in overall infected subjects. In H.pylori-uninfected subjects, there was no association between -94 ins/del ATTG polymorphism and CIHM.

The association of $-449 \mathrm{G}>\mathrm{C}$ with CIHM was similar to that of -94 ins/del ATTG with CIHM (Table III), because both polymorphisms were in strong linkage disequilibrium. So, in H. pylori-infected subjects over 60-years-old, -449 GG homozygote had an increased risk for CIHM (OR, 3.31; 95\%CI, 1.04-10.6; $\mathrm{p}=0.044)$.

In $H$. pylori-infected over 60 -year-old subjects, both -94 del/del ATTG and -449 GG homozygote had an increased risk for the development of $D A P K$ methylation (OR, 5.35; 95\% CI, 1.17-24.5; $\mathrm{p}=0.031$ and $\beta=0.726$; and $\mathrm{OR}, 3.75 ; 95 \%$ CI, 1.04-13.6; $\mathrm{p}=0.044$, respectively) (Table IV). In addition, 
Table II. Association between NFKB1-94 ins/del ATTG polymorphism and CIHM.

\begin{tabular}{|c|c|c|c|c|c|}
\hline & \multicolumn{3}{|c|}{ Genotype (n) } & \multirow{2}{*}{$\frac{\text { del/del vs. ins carrier }}{\text { OR }(95 \% \mathrm{CI})}$} & \multirow[b]{2}{*}{$\mathrm{p}$-value } \\
\hline & ins/ins & ins/del & $\mathrm{del} / \mathrm{del}$ & & \\
\hline \multicolumn{6}{|l|}{ H. pylori-infected } \\
\hline \multicolumn{6}{|l|}{ Overall } \\
\hline Non-CIHM (n=107) & 40 & 57 & 10 & Reference value & - \\
\hline CIHM (n=136) & 50 & 65 & 21 & $1.58(0.698-3.56)$ & 0.27 \\
\hline \multicolumn{6}{|l|}{$60 \leq$} \\
\hline Non-CIHM (n=61) & 23 & 35 & 3 & Reference value & - \\
\hline CIHM (n=81) & 27 & 39 & 15 & $4.16(1.14-15.3)$ & 0.031 \\
\hline \multicolumn{6}{|l|}{ H.pylori-uninfected } \\
\hline \multicolumn{6}{|l|}{ Overall } \\
\hline Non-CIHM $(n=112)$ & 45 & 50 & 17 & Reference value & - \\
\hline CIHM (n=47) & 19 & 20 & 8 & $1.15(0.456-2.88)$ & 0.77 \\
\hline \multicolumn{6}{|l|}{$60 \leq$} \\
\hline Non-CIHM $(n=56)$ & 21 & 25 & 10 & Reference value & - \\
\hline CIHM (n=27) & 13 & 10 & 4 & $0.814(0.228-2.91)$ & 0.75 \\
\hline
\end{tabular}

Logistic regression analysis after adjustment for age and gender; CIHM, CpG island high methylation group

Table III. Association between NFKB1-449 C>G polymorphism and CIHM.

\begin{tabular}{|c|c|c|c|c|c|}
\hline & \multicolumn{3}{|c|}{ Genotype (n) } & \multirow{2}{*}{$\frac{\text { GG vs. C carrier }}{\text { OR }(95 \% \mathrm{CI})}$} & \multirow[b]{2}{*}{ p-value } \\
\hline & $\mathrm{CC}$ & $\mathrm{CG}$ & GG & & \\
\hline \multicolumn{6}{|l|}{ H. pylori-infected } \\
\hline \multicolumn{6}{|l|}{ Overall } \\
\hline Non-CIHM (n=107) & 42 & 52 & 13 & Reference value & - \\
\hline CIHM (n=136) & 48 & 65 & 23 & $1.30(0.612-2.74)$ & 0.50 \\
\hline \multicolumn{6}{|l|}{$60 \leq$} \\
\hline Non-CIHM (n=61) & 25 & 32 & 4 & Reference value & - \\
\hline CIHM (n=81) & 27 & 38 & 16 & $3.31(1.04-10.6)$ & 0.044 \\
\hline \multicolumn{6}{|l|}{ H. pylori-uninfected } \\
\hline \multicolumn{6}{|l|}{ Overall } \\
\hline Non-CIHM $(n=112)$ & 48 & 45 & 19 & Reference value & - \\
\hline CIHM $(n=47)$ & 18 & 20 & 9 & $1.14(0.473-2.75)$ & 0.77 \\
\hline \multicolumn{6}{|l|}{$60 \leq$} \\
\hline Non-CIHM $(n=56)$ & 23 & 22 & 11 & Reference value & - \\
\hline CIHM (n=27) & 12 & 10 & 5 & $0.939(0.287-3.07)$ & 0.92 \\
\hline
\end{tabular}

Logistic regression analysis after adjustment for age and gender; CIHM, CpG island high methylation group

-94 del/del homozygote had an increased risk for $C D H 1$, as well as $D A P K$, methylation (OR, 2.91; 95\% CI, 1.02-8.30; $\mathrm{p}=0.046)$. On the other hand, both polymorphisms were not associated with $C D K N 2 A\left(p 14^{A R F}\right.$ and $\left.p 16^{I N K 4 a}\right)$ methylation.

Relationship between NFKB1 polymorphisms and methylated gene number. We found strong allelic association between
-94 ins/del ATTG and $-449 \mathrm{C}>\mathrm{G}$. That is, 66 of $68 \mathrm{del} / \mathrm{del}$ homozygote had $-449 \mathrm{GG}$ genotype. In $H$. pylori-infected subjects, all of $39 \mathrm{del} / \mathrm{del}$ homozygote had -449 GG genotype. Therefore, we investigated the association of only -94 ins/del ATTG polymorphism with gastric inflammation and gene methylation. In $H$. pylori-infected subjects over 60 -years-old or more, methylated gene number was significantly higher in 
Table IV. Associations between NFKB1 polymorphisms and each gene methylation in the $H$. pylori-infected subjects older than 60-year-old.

\begin{tabular}{|c|c|c|c|c|c|}
\hline -94 ATTG ins/del & ins/ins & ins/del & del/del & del/del vs. ins carrier; OR $(95 \% \mathrm{CI})$ & p-value \\
\hline$p 14^{A R F}$-unmethylated $(\mathrm{n}=86)$ & 35 & 39 & 12 & Reference value & - \\
\hline$p 14^{A R F}$-methylated $(\mathrm{n}=56)$ & 15 & 35 & 6 & $0.661(0.228-1.92)$ & 0.45 \\
\hline pl $6^{I N K 4 a}$-unmethylated $(\mathrm{n}=90)$ & 29 & 52 & 9 & Reference value & - \\
\hline pl6 $6^{I N K 4 a}$-methylated $(\mathrm{n}=52)$ & 21 & 22 & 9 & $1.83(0.671-4.97)$ & 0.24 \\
\hline CDH1-unmethylated $(\mathrm{n}=79)$ & 29 & 44 & 6 & Reference value & - \\
\hline$C D H 1$-methylated $(\mathrm{n}=63)$ & 21 & 30 & 12 & $2.91(1.02-8.30)$ & 0.046 \\
\hline$D A P K$-unmethylated $(\mathrm{n}=53)$ & 19 & 32 & 2 & Reference value & - \\
\hline$D A P K$-methylated $(\mathrm{n}=89)$ & 31 & 42 & 16 & $5.35(1.17-24.5)$ & 0.031 \\
\hline$-449 \mathrm{C}>\mathrm{G}$ & $\mathrm{CC}$ & $\mathrm{CG}$ & GG & GG vs. C carrier; OR (95\% CI) & $\mathrm{p}$-value \\
\hline$p 14^{A R F}$-unmethylated $(\mathrm{n}=86)$ & 37 & 37 & 12 & Reference value & - \\
\hline$p 14^{A R F}$-methylated $(\mathrm{n}=56)$ & 15 & 33 & 8 & $0.925(0.346-2.48)$ & 0.88 \\
\hline pl6 $6^{I N K 4 a}$-unmethylated $(\mathrm{n}=90)$ & 31 & 48 & 11 & Reference value & - \\
\hline p16 $6^{I N K 4 a}$-methylated $(\mathrm{n}=52)$ & 21 & 22 & 9 & $1.45(0.555-3.81)$ & 0.45 \\
\hline CDHI-unmethylated $(\mathrm{n}=79)$ & 31 & 40 & 8 & Reference value & - \\
\hline$C D H 1$-methylated $(\mathrm{n}=63)$ & 21 & 30 & 12 & $2.12(0.802-5.59)$ & 0.13 \\
\hline$D A P K$-unmethylated $(\mathrm{n}=53)$ & 20 & 30 & 3 & Reference value & - \\
\hline$D A P K$-methylated $(\mathrm{n}=89)$ & 32 & 40 & 17 & $3.75(1.04-13.6)$ & 0.044 \\
\hline
\end{tabular}

Logistic regression analysis after adjustment for age and gender.

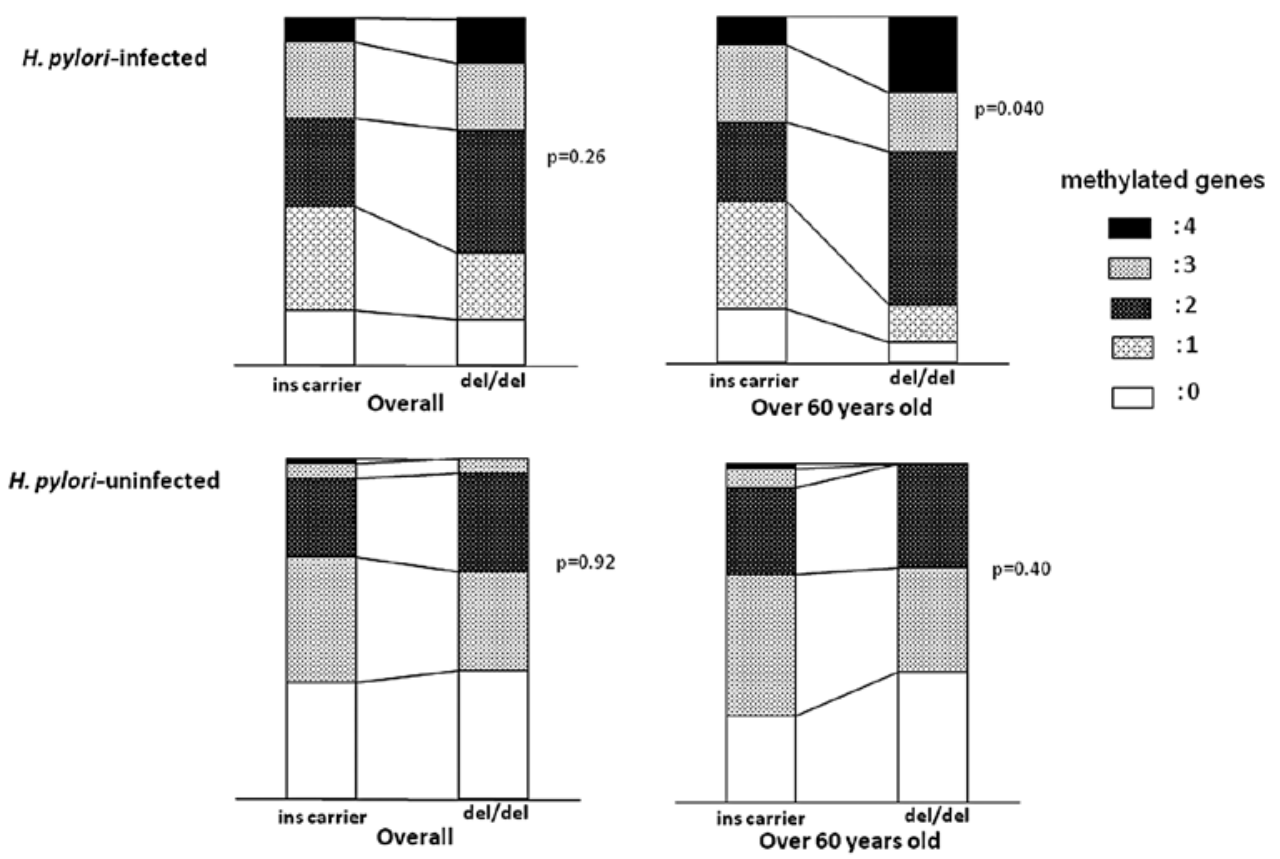

Figure 2. The number of methylated genes and NFKB1 genotype. In H.pylori-infected subjects over 60 -years-old, methylated gene number was significantly higher in del/del homozygote than ins carrier. A p-value was calculated by ANOVA.

del/del homozygotes than in ins carriers ( $\mathrm{p}=0.040$ by ANOVA) (Fig. 2), although no significant difference was seen in overall $H$. pylori-infected subjects. In $H$. pylori-uninfected subjects, there was no significant difference in the methylated gene number among two genotypes.
In $H$. pylori-infected del/del homozygote, methylated gene number was significantly correlated to age $(p=0.027$ by ANOVA) (Fig. 3), whereas no significant correlation was seen in the $H$. pylori-infected ins carrier and the uninfected groups. 


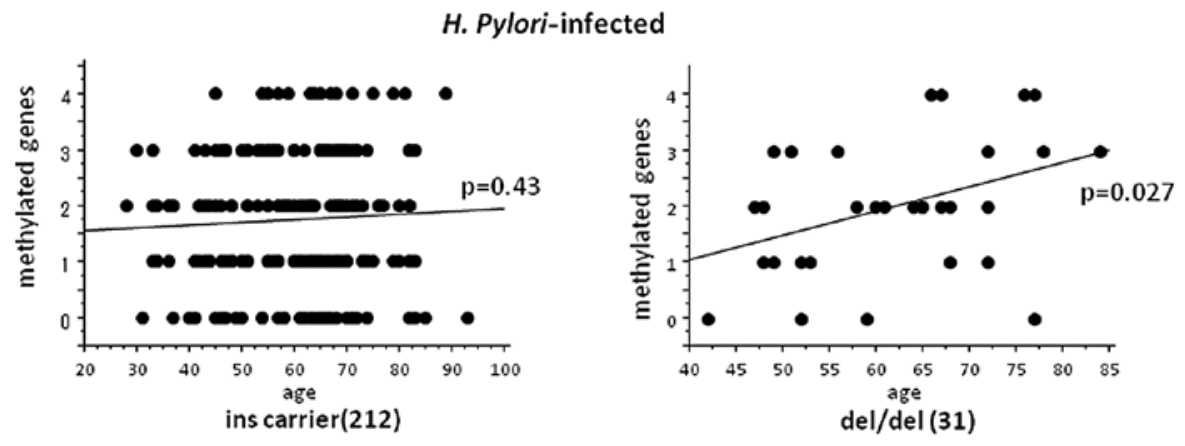

H. Pylori-uninfected
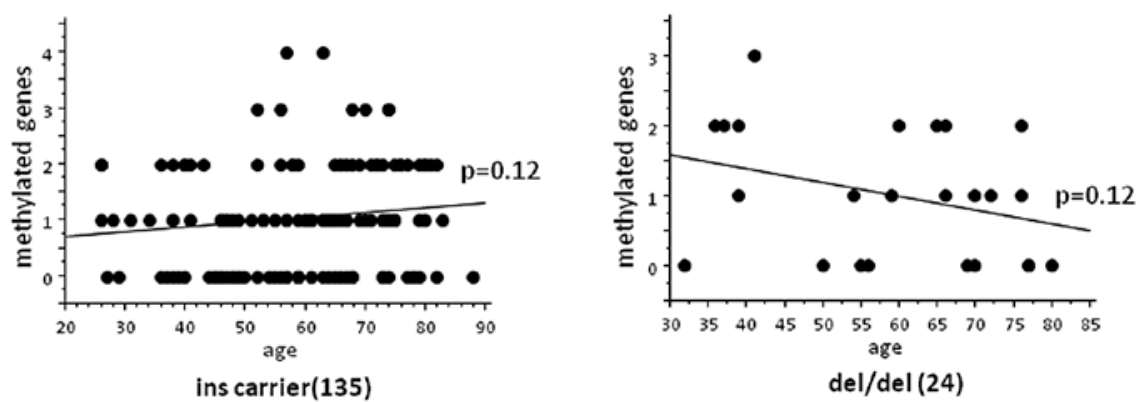

Figure 3. Correlation of the number of methylated genes to age by H.pylori infection status and genotype. In H.pylori-infected del/del homozygote, methylated gene number was significantly correlated to age. A p-value was calculated by ANOVA.

Table V. Comparison of each updated Sydney system score among del/del and ins carrier.

\begin{tabular}{lccc}
\hline H. pylori-infected & del $/ \mathrm{del}(\mathrm{n}=28)$ & ins carrier $(\mathrm{n}=228)$ & $\mathrm{p}$-value \\
\hline Activity & $0.929 \pm 0.813$ & $0.851 \pm 0.858$ & $\mathrm{NS}$ \\
Inflammation & $2.179 \pm 0.476$ & $1.860 \pm 0.628$ & 0.0091 \\
Atrophy & $1.607 \pm 0.685$ & $1.575 \pm 0.773$ & $\mathrm{NS}$ \\
Metaplasia & $0.786 \pm 1.067$ & $0.982 \pm 1.015$ & $\mathrm{NS}$ \\
\hline & & & $\mathrm{p}$-value \\
H. pylori-uninfected & del $/ \mathrm{del}(\mathrm{n}=15)$ & ins carrier $(\mathrm{n}=129)$ & $\mathrm{NS}$ \\
\hline Activity & $0.067 \pm 0.258$ & $0.155 \pm 0.441$ & $\mathrm{NS}$ \\
Inflammation & $0.533 \pm 0.516$ & $0.659 \pm 0.667$ & $\mathrm{NS}$ \\
Atrophy & $0.133 \pm 0352$ & $0.326 \pm 0.614$ & $\mathrm{NS}$ \\
Metaplasia & 0 & $0.109 \pm 0.437$ &
\end{tabular}

Statistical anaysis was performed by the Mann-Whitney U-test. NS, not significant.

Comparison of each updated Sydney system score among del-G and non-del-G groups. In H.pylori-infected subjects, the inflammation score was significantly higher in del/del homozygote than ins carrier ( $\mathrm{p}=0.0091$ by Mann-Whitney U-test), whereas the other scores were not different among two genotypes (Table V). In H. pylori-uninfected subjects, there were no significant differences of all scores among two genotypes.

\section{Discussion}

Accumulation of DNA damage and aberrant methylation of various genes in gastric mucosa were induced by $H$. pylori infection and confer risk for developing gastric cancer.
However, all the $H$. pylori-infected patients do not show the same hypermethylation status of genes. This suggests that some host genetic factor, such as genetic variations related to the immune response or inflammation, may be relevant to the hypermethylation of genes during gastric carcinogenesis.

Here, we evaluated the association between $N F K B 1$, encoding NF- $\kappa \mathrm{B}$ which plays an important role in inflammation and carcinogenesis, polymorphisms and aberrant methylation of genes in non-neoplastic gastric mucosa. NFKB1 -94 ins/del ATTG and $-449 \mathrm{C}>\mathrm{G}$ was in linkage disequilibrium and all of $39 \mathrm{H}$. pylori-infected -94 del/del homozygote had the $-449 \mathrm{GG}$ genotype. Therefore, the effects of the -94 and -449 mutant haplotype was equal to that of the -94 mutant variation. In 
the present study, we demonstrated that the -94 del/del ATTG homozygotes had increased risk of aberrant methylation of $D A P K$ and $C D H 1$ in comparatively older $H$. pylori-infected subjects. We also found that in $H$. pylori-infected del/del homozygotes, the number of methylated genes was higher in subjects over 60-years-old and was correlated to age. In addition, gastric mucosal inflammation was more severe in infected del/del homozygotes. These findings suggest that, in the NFKB1 -94 del/del ATTG homozygote, H. pylori infection may accelerate severe mucosal inflammation, resulting in high age-related gene methylation. The methylation of genes is frequently observed in $H$. pylori-infected non-neoplastic mucosa (17-19), and is closely correlated with gastric cancer occurrence $(12,18,20)$. Therefore, this epigenetic effect seems to be an early step in carcinogenesis in the stomach. Our data suggest that $N F K B 1$ polymorphisms may have a role in gastric carcinogenesis in the early phase via gene methylation-related pathway. In the present study, sample selection may affect the outcome, because our subjects came to hospital in order to have endoscopic examination for the compliant of abdominal discomfort, or for complete check up of gastric cancer following to barium X-ray examination in the health check, not complete healthy subjects. Moreover, the effect of type II error cannot be excluded in relatively small sample sizes. Another limitation of this study was that the male/female ratio was different among $H$. pylori-infected and uninfected subjects. However, adjustment of age and gender was performed in genotype analysis using logistic regression.

It has been reported that the NFKB1 -94 ATTG deletion variant in the promoter region destroys a transcription factor binding site, resulting in lower expression of NF- $\mathrm{BB}$ (28). Due to their important role in inflammation, the lower expression of $\mathrm{NF}-\kappa \mathrm{B}$ protein seems to suppress inflammation. Furthermore, the NFKB1 -94 deletion mutant has been associated with reduced risk for the auto-immune disorders in China (29). In stomach, Lo et al (30) showed that -94 deletion variant had a significantly reduced risk for the gastric carcinogenesis in China. For hepatocarcinogenesis, He et al (31) also showed that -94 deletion mutant had a reduced risk under the influence of hepatitis B virus infection in China. Contrary to these results, several studies have showed that -94 deletion variant is associated with increased risk for the development of inflammatory or auto-immune diseases in Caucasian $(28,29,32)$. In colorectal carcinogenesis, Andersen et al (33) have showed that carriers of NFKB1 -94 deletion were at 1.45-fold higher risk than homozygous carriers of the insertion allele. On the other hand, the lack of an association between the NFKB1-94 ins/del polymorphism and the inflammatory or autoimmune diseases has also been reported (34-37). These contrasting observations may be explained by differences in the genotypic composition of populations in different countries with different racial groups. In fact, the frequency of -94 deletion allele seems to be rather higher in Chinese healthy subjects (45-55\%). However, in our study of Japanese subjects, the frequency was $\sim 38 \%$, similar to the value in Caucasians. Our study as well as the Caucasian study indicate that the -94 deletion variant may be an inflammation promoting allele.

$\mathrm{NF}-\kappa \mathrm{B}$ encompasses a number of different transcription factors that are homo- or heterodimers of p65, p50, p105, c-Rel and RelB (38). NF- $\mathrm{BB}$ is involved in both inflammatory and anti-inflammatory process (39). The role of NF- $\mathrm{NB}$ in inflammation is determined by the subunit type. $N F K B 1$ encodes both the subunits p105 and p50 of the transcription factor $\mathrm{NF}-\kappa \mathrm{B}$ by alternative splicing (40). As part of the p65/p50 $\mathrm{NF}-\kappa \mathrm{B}$ transcription factor complex, it is pro-inflammatory, controlling transcription of pro-inflammatory cytokines (41). Conversely, since p50 lacks this $\mathrm{COOH}$-terminal transactivation domain which is necessary for the positive regulation of gene expression, p50 has anti-inflammatory properties in the p50 homodimer by repressing transcription (42). The relative abundance of p65/p50 heterodimers and p50 homodimers may determine the magnitude of inflammation by balancing the pro-inflammatory and anti-inflammatory response (38). In fact, p50-deficient mice have an increased sensitivity to lipopolysaccharide (LPS) and have increased LPS-induced inflammation $(43,44)$. In subjects with the del/del genotype, decreased p50 synthesis may lead to decreased repressive homodimers and increased active heterodimers of the NF- $\kappa \mathrm{B}$ complex. This balance may promote the $H$. pylori-induced inflammation, resulting in hypermethylation of genes.

In current study, 66 of $68 \mathrm{del} / \mathrm{del}$ homozygotes had the -449 GG genotype and, all of $39 \mathrm{del} / \mathrm{del}$ homozygotes had the -449 GG genotype in $H$. pylori-infected subjects. Therefore, we suspect that -94 ins/del ATTG polymorphism may mainly regulate the expression and function of $\mathrm{NF}-\kappa \mathrm{B}$. From our results in this study, we could not show the role of $-449 \mathrm{C}>\mathrm{G}$ polymorphism. Our results showed that, in $-94 \mathrm{del} / \mathrm{del}$ homozygote, gastric inflammation was more severe and gene methylation was promoted over 60 -year-old under influence of $H$. pylori infection. Because NF- $\mathrm{NB}$ is activated by some stimulation such as infection and stress, it is reasonable that $N F K B 1$ polymorphism is associated with the gastric inflammation process under $H$. pylori infection. In addition, it is also reasonable that increased gene methylation is revealed in elder subjects, because gene methylation gradually progresses with age and accumulates for a long time. Interestingly, although gastric inflammation was more severe in $-94 \mathrm{del} / \mathrm{del}$ homozygote, atrophy and metaplasia scores were not different among del/del homozygote and ins carrier. This reason is unclear. The decreased p50 production may affect the action of not only the p50 homodimer but also of the p65/p50 heterodimer.

In conclusion, the NFKB1 -94 ins/del ATTG polymorphism (rs28362491) was significantly associated with an increased risk for the development of age related-gene methylations in non-cancerous gastric mucosa under H.pylori-induced inflammation. The -94 del/del homozygote may have an increased risk for the development of age-related and inflammationinduced gene methylation, as a precancerous condition, in gastric mucosa.

\section{References}

1. Correa P: Human gastric carcinogenesis: a multistep and multifactorial process - First American Cancer Society Award Lecture on Cancer Epidemiology and Prevention. Cancer Res 52: 6735-6740, 1992.

2. Kiechl S, Lorenz E, Reindl M, et al: Toll-like receptor 4 polymorphisms and atherogenesis. N Engl J Med 347: 185-192, 2002.

3. Hoshino K, Takeuchi O, Kawai T, et al: Cutting edge: Toll-like receptor 4 (TLR4)-deficient mice are hyporesponsive to lipopolysaccharide: evidence for TLR4 as the Lps gene product. J Immunol 162: 3749-3752, 1999. 
4. Keates S, Hitti YS, Upton M and Kelly CP: Helicobacter pylori infection activates NF-kappa B in gastric epithelial cells. Gastroenterology 113: 1099-1109, 1997.

5. Hatz RA, Rieder G, Stolte M, et al: Pattern of adhesion molecule expression on vascular endothelium in Helicobacter pylori associated antral gastritis. Gastroenterology 112: 1908-1919, 1997.

6. Maeda S, Yoshida H, Ogura K, et al: $H$. pylori activates NF-kappaB through a signaling pathway involving IkappaB kinases, NF-kappaB-inducing kinase, TRAF2, and TRAF6 in gastric cancer cells. Gastroenterology 119: 97-108, 2000.

7. Smith MG, Hold GL, Tahara E and El-Omar EM: Cellular and molecular aspects of gastric cancer. World J Gastroenterol 12 2979-2990, 2006.

8. Parsonnet J, Friedman GD, Vandersteen DP, et al: Helicobacter pylori infection and the risk of gastric carcinoma. $\mathrm{N}$ Engl J Med 325: 1127-1131, 1991.

9. Blaser MJ and Parsonnet J: Parasitism by the 'slow' bacterium Helicobacter pylori leads to altered gastric homeostasis and neoplasia. J Clin Invest 94: 4-8, 1994.

10. Huang JQ, Sridhar S, Chen Y and Hunt RH: Meta-analysis of the relationship between Helicobacter pylori seropositivity and gastric cancer. Gastroenterology 114: 1169-1179, 1998.

11. Esteller M, Corn PG, Baylin SB and Herman JG: A gene hypermethylation profile of human cancer. Cancer Res 61: 3225-3229, 2001 .

12. Tahara T, Shibata T, Nakamura M, et al: Increased number of $\mathrm{CpG}$ island hypermethylation in tumor suppressor genes of nonneoplastic gastric mucosa correlates with higher risk of gastric cancer. Digestion 82: 27-36, 2010.

13. Issa JP, Ottaviano YL, Celano P, Hamilton SR, Davidson NE and Baylin SB: Methylation of the oestrogen receptor $\mathrm{CpG}$ island links ageing and neoplasia in human colon. Nat Genet 4: 536-540, 1994.

14. Ahuja N, Li Q, Mohan AL, Baylin SB and Issa JP: Aging and DNA methylation in colorectal mucosa and cancer. Cancer Res 23: 5489-5494, 1998

15. Issa JP, Ahuja N, Toyota M, Bronner MP and Brentnall TA Accelerated age-related $\mathrm{CpG}$ island methylation in ulcerative colitis. Cancer Res 61: 3573-3577, 2001.

16. Bian YS, Osterheld MC, Fontolliet C, Bosman FT and Benhattar J: p16 inactivation by methylation of the CDKN2A promoter occurs early during neoplastic progression in Barrett's esophagus. Gastroenterology 122: 1113-1121, 2001.

17. Maekita T, Nakazawa K, Mihara M, et al: High levels of aberrant DNA methylation in Helicobacter pylori-infected gastric mucosae and its possible association with gastric cancer risk. Clin Cancer Res 12: 989-995, 2006.

18. Tahara T, Arisawa T, Sibata T, et al: Risk prediction of gastric cancer by analysis of aberrant DNA methylation in non-neoplastic gastric epithelium. Digestion 75: 54-61, 2007.

19. Kang GH, Lee HJ, Hwang KS, Lee S, Kim JH and Kim JS Aberrant $\mathrm{CpG}$ island hypermethylation of chronic gastritis, in relation to aging, gender, intestinal metaplasia, and chronic inflammation. Am J Pathol 163: 1551-1556, 2003.

20. Kang GH, Lee S, Lim JS and Jung HY: Profile of aberrant CpG island methylation along the multistep pathway of gastric carcinogenesis. Lab Invest 83: 635-641, 2003.

21. Zou YF, Wang F, Feng XL, et al: Association of NFKB1 -94ins/ delATTG promoter polymorphism with susceptibility to autoimmune and inflammatory diseases: a meta-analysis. Tissue Antigens 77: 9-17, 2010.

22. Zou YF, Yuan FL, Feng XL, et al: Association between NFKB1 -94ins/delATTG promoter polymorphism and cancer risk: a meta-analysis. Cancer Invest 29: 78-85, 2010.

23. Tahara T, Arisawa T, Shibata T, et al: Increased number of methylated $\mathrm{CpG}$ islands correlates with Helicobacter pylori infection, histological and serological severity of chronic gastritis. Eur J Gastroenterol Hepatol 21: 613-619, 2009.
24. Tahara T, Shibata T, Arisawa T, et al: Impact of catecholO-methyltransferase (COMT) gene polymorphism on promoter methylation status in gastric mucosa. Anticancer Res 29: 2857-2861, 2009.

25. Arisawa T, Tahara T, Shibata T, et al: The relationship between Helicobacter pylori infection and promoter polymorphism of the Nrf2 gene in chronic gastritis. Int J Mol Med 19: 143-148, 2007.

26. Shiroeda $\mathrm{H}$, Tahara T, Shibata T, et al: Functional promoter polymorphisms of macrophage migration inhibitory factor (MIF) in peptic ulcer diseases. Int J Mol Med 26: 707-711, 2010

27. Dixon MF, Genta RM, Yardley JH and Correa P: Classification and grading of gastritis: the updated Sydney system. Am J Surg Pathol 20: 1161-1181, 1996.

28. Karban AS, Okazaki T, Panhuysen CI, et al: Functional annotation of a novel NFKB1 promoter polymorphism that increases risk for ulcerative colitis. Hum Mol Genet 13: 35-45, 2004.

29. Li H, Gao L, Shen Z, et al: Association study of NFKB1 and SUMO4 polymorphisms in Chinese patients with psoriasis vulgaris. Arch Dermatol Res 300: 425-433, 2008.

30. Lo SS, Chen JH, Wu CW and Lui WY: Functional polymorphism of NFKB1 promoter may correlate to the susceptibility of gastric cancer in aged patients. Surgery 145: 280-285, 2009.

31 . He Y, Zhang $\mathrm{H}$, Yin J, et al: I $\kappa \mathrm{B} \alpha$ gene promoter polymorphisms are associated with hepatocarcinogenesis in patients infected with hepatitis B virus genotype C. Carcinogenesis 30: 1916-1922, 2009.

32. Kurylowicz A, Hiromatsu Y, Jurecka-Lubieniecka B, et al: Association of NFKB1-94ins/del ATTG promoter polymorphism with susceptibility to and phenotype of Graves' disease. Genes Immun 8: 532-538, 2007.

33. Andersen V, Christensen J, Overvad K, Tjønneland A and Vogel U: Polymorphisms in NFKB, PXR, LXR and risk of colorectal cancer in a prospective study of Danes. BMC Cancer 10: 484, 2010

34. Martínez A, Sánchez E, Valdivia A, et al: Epistatic interaction between FCRL3 and NFkappaB1 genes in Spanish patients with rheumatoid arthritis. Ann Rheum Dis 65: 1188-1191, 2006.

35. Mirza MM, Fisher SA, Onnie C, et al: No association of the NFKB1 promoter polymorphism with ulcerative colitis in a British case control cohort. Gut 54: 1205-1206, 2005.

36. Glas J, Török HP, Tonenchi L, et al: Role of the NFKB1 -94ins/ delATTG promoter polymorphism in IBD and potential interactions with polymorphisms in the CARD15/NOD2, IKBL, and IL-1RN genes. Inflamm Bowel Dis 12: 606-611, 2006.

37. Bajwa EK, Cremer PC, Gong MN, et al: An NFKB1 promoter insertion/deletion polymorphism influences risk and outcome in acute respiratory distress syndrome among Caucasians. PLoS One 6: e19469, 2011.

38. Pereira SG and Oakley F: Nuclear factor-kappaB1: regulation and function. Int J Biochem Cell Biol 40: 1425-1430, 2008.

39. de Winther MP, Kanters E, Kraal G and Hofker MH: Nuclear factor kappaB signaling in atherogenesis. Arterioscler Thromb Vasc Biol 25: 904-914, 2005.

40. Lin L, DeMartino GN and Greene WC: Cotranslational biogenesis of NF-kappaB p50 by the $26 \mathrm{~S}$ proteasome. Cell 92 : 819-828, 1998

41. Perkins ND: Integrating cell-signalling pathways with NF-kappaB and IKK function. Nat Rev Mol Cell Biol 8: 49-62, 2007.

42. Hayden MS and Ghosh S: Shared principles in NF-kappaB signaling. Cell 132: 344-362, 2008.

43. Gadjeva M, Tomczak MF, Zhang M, et al: A role for NF-kappaB subunits p50 and p65 in the inhibition of lipopolysaccharideinduced shock. J Immunol 173: 5786-5793, 2004.

44. Han W, Joo M, Everhart MB, et al: Myeloid cells control termination of lung inflammation through the NF-kappaB pathway. Am J Physiol Lung Cell Mol Physiol 296: L320-L327, 2009. 